\title{
SOCIAL SCIENCE
}

\section{International Journal of Environmental, Sustainability, and Social Sciences}

ISSN 2720-9644 (print); ISSN 2721-0871 (online)

https://journalkeberlanjutan.com/index.php/IJESSS

Volume 1

Nomor 1

March 2020

Page 36-40

\section{Article History:}

Received: 2020-02-28

Revised: 2020-03-09

Accepted: 2020-03-28

\section{FACTOR INFLUENCE MENTAL IN ADOLENCES}

1 Alva Cherry MUSTAMU, ${ }^{2}$ Nur Hafni HASIM, 3Furaida KHASANAH

1,2 Poltekkes Kemenkes Sorong, Papua Barat, Indonesia

3 Poltekkes Kemenkes Yogyakarta, Yogyakarta, Indonesia

Corresponding author: Alva Cherry Mustamu, Poltekkes Kemenkes Sorong, Papua Barat, Indonesia

E-mail: alvamustamu@gmail.com

\section{Abstract:}

The mental condition of adolescents and children in Indonesia is currently alarming. Adolescents are vulnerable to various problems at the stage of development, such as mental and emotional problems related to emotional disturbances, depression, resistance, and behavioral disorders. The behavior or actions that arise by each individual depends on the emotional and thought conditions that arise before they decide to do something. The research is a descriptive-analytic study with a cross-sectional design aimed to determine the conditions that affect mental health in 80 teenage students of SMK Negeri 1 Sorong. The measuring instrument used was a questionnaire. Simple logistic regression analysis test results show that parenting style, motivation, and discipline simultaneously have an effect on adolescent mental health with a significance value $(0,000<0.005)$. Discipline, learning motivation has an influence on adolescent mental health with a significance value $(0,000<0.005)$, but parenting does not affect adolescent mental health with a significance value $(0.382>0.005)$. Adolescents need support, including the environment, to prevent mental disorders because it has a close relationship with academic success.

\section{Keywords:}

Adolescents, Discipline, Mental Health, Motivation, Parenting Style

Cite this as Mustamu, A.C., Hasim, N.H., Khasanah, F., (2020). Factor Influence Mental In Adolescents. International Journal of Environmental, Sustainability, and Social Science, 1(1), 36-40. https://doi.org/10.38142/ijesss.v1i1.40

\section{INTRODUCTION}

Adolescence is a unique and formative period due to various physical, emotional, and social changes, including exposure to poverty, abuse, or violence, which make adolescents vulnerable to mental health problems. Begin Promoting psychological well-being and protecting adolescents from bad experiences and risk factors that can affect their potential to develop is very important for their physical and mental health well-being in adulthood.

It is estimated that $10-20 \%$ of adolescents globally experience mental health conditions, but this is still poorly diagnosed and treated (Vereinte Nationen \& Büro für Drogenkontrolle und Verbrechensbekämpfung, 2019; WHO, 2019). Depression and anxiety have adverse consequences on adolescent development, including achieving lower education, dropping out of school, disruption of social relations, and an increased risk of substance abuse, mental health problems and suicide (Hetrick et al., 2016)

Many factors determine mental health outcomes. The more risk factors faced by adolescents, the greater the potential impact on their mental health. Some adolescents are at greater risk from mental health conditions because of their living conditions, stigma, discrimination or exclusion, or lack of access to quality support and services.

The WHO Mental Health Action Plan, 2013-2020, incorporates the concepts of mental health promotion, prevention and treatment of mental illness, and rehabilitation. In particular, aspects of the development of children and adolescents, including, for example, the ability to manage thoughts, emotions, and build social relationships, and the talent for learning, are emphasized in plans as critical aspects that must be dealt with mentally.

In Indonesia, most children of this age are still undergoing an education at school. There is sufficient supporting evidence about the potential of these interventions for schools to create a positive climate based on instructional and emotional support, solidarity, and friendship that enhance the welfare of children and society (Bloemraad \& Terriquez, 2016; Puffer et al., 2016). However, the problem is whether the school can create a positive climate so that adolescents do not experience mental problems or the school instead becomes a media of mental problems.

The literature analyzed highlights the importance of preventive interventions in which different agents work together towards a common goal of promoting the mental health of children and adolescents (Atkins et 


\section{SOCIAL SCIENCE}

\section{International Journal of Environmental, Sustainability, and Social Sciences \\ ISSN 2720-9644 (print); ISSN 2721-0871 (online) \\ https://journalkeberlanjutan.com/index.php/IJESSS}

al., 2015; Kia-Keating et al., 2017). But to find a solution to the problem, it must be known in advance the root of the problem that has been causing interference or mental instability in them

\section{METHOD}

This study was an observational analytic study using a cross-sectional study to determine the factors that influence the mental health of 80 adolescents 12-17 years old at SMK Negeri 1 Sorong taken using consecutive sampling. Materials and research tools used were 4 questionnaires, namely Parental Authority Questionnaire-Revision (PAQ-R) (Reitman et al., 2002), disciplinary and motivational questionnaire (Suranto, 2009) and General Mental Health (Dwairy \& Menshar, 2006). The ethics committee approved this study of the Sorong Health Ministry of Health Poltekkes. Analysis of research data using simple logistic regression analysis.

\section{RESULTS AND DISCUSSION}

Table 1 explains in detail the characteristics of the participants. Most respondents were in the tenth grade, which was around 17 years old, were female, lived with parents with high school education, worked as private employees. Parenting patterns are negative but have high motivation and discipline so that they have good mental health. As for the characteristics of respondents based on age at SMK 1 Sorong, West Papua, Indonesia, as follows:

Table 1 Sociodemographic of Respondents

\begin{tabular}{|c|c|c|}
\hline Variable & $\mathbf{n}$ & $\%$ \\
\hline \multicolumn{3}{|l|}{ Grade } \\
\hline Ten & 48 & 60 \\
\hline Eleven & 16 & 20 \\
\hline Twelve & 16 & 20 \\
\hline \multicolumn{3}{|l|}{ Sex } \\
\hline Male & 35 & 43,08 \\
\hline Female & 45 & 56 \\
\hline \multicolumn{3}{|l|}{ Live with parents } \\
\hline No & 4 & 5 \\
\hline Yes & 76 & 95 \\
\hline \multicolumn{3}{|l|}{ Parental education } \\
\hline None & 2 & 2.05 \\
\hline Junior high school & 2 & 2.05 \\
\hline Senior high school & 42 & 52.05 \\
\hline University & 34 & 42.05 \\
\hline \multicolumn{3}{|l|}{ Parents profession } \\
\hline Does not work/ housewife & 2 & 2.05 \\
\hline Government employees & 32 & 40 \\
\hline Private business & 39 & 48.08 \\
\hline Farmers / workers / entrepreneurs & 7 & 8.08 \\
\hline \multicolumn{3}{|l|}{ Disciplinary score } \\
\hline Undisciplined & 11 & 13.08 \\
\hline Discipline & 69 & 86.02 \\
\hline \multicolumn{3}{|l|}{ Motivation score } \\
\hline Low & 12 & 15 \\
\hline High & 68 & 85 \\
\hline \multicolumn{3}{|l|}{ Parenting style score } \\
\hline Negative & 63 & 78.08 \\
\hline Positive & 17 & 21.02 \\
\hline \multicolumn{3}{|l|}{ Mentally healthy score } \\
\hline Mental disorders & 12 & 15 \\
\hline Mental healthy & 68 & 85 \\
\hline
\end{tabular}

Table 2 shows that parenting, motivation, and discipline simultaneously affect adolescent mental health.

Tabel 2. Simultaneous significance test results ( $F$ test).

\begin{tabular}{lccccc}
\multicolumn{1}{c}{ Model } & Sum of Squares & df & Mean Square & F & Sig \\
\hline Regression & 9.418 & 4 & 3.139 & 305.175 & 0.000 \\
Residual & 0.782 & 76 & 0.010 & & \\
Total & 10.200 & 80 & & & \\
\hline
\end{tabular}




\section{SOCIAL SCIENCE}

\section{International Journal of Environmental, Sustainability, and Social Sciences ISSN 2720-9644 (print); ISSN 2721-0871 (online) \\ https://journalkeberlanjutan.com/index.php/IJESSS}

Table 3 shows that discipline and motivation have a linear relationship with mental health. However, parenting does not have a linear relationship to adolescent mental health.

Tabel 3. Significance results of the partial influence

\begin{tabular}{|c|c|c|c|c|c|}
\hline \multirow[t]{2}{*}{ Model } & \multicolumn{2}{|c|}{ UnStandardized Coefficient } & \multirow{2}{*}{$\begin{array}{c}\text { Standardized } \\
\text { Coefficient } \\
\text { Beta }\end{array}$} & \multirow[t]{2}{*}{$\mathbf{t}$} & \multirow[t]{2}{*}{ Sig } \\
\hline & B & Std. Error & & & \\
\hline (Constant) & -0.038 & 0.032 & & -1.207 & 0.231 \\
\hline Disciplinary & 0.820 & 0.050 & 0.791 & 16.517 & 0.000 \\
\hline Motivation & 0.215 & 0.049 & 0.215 & 4.405 & 0.000 \\
\hline Parenting Style & -0.007 & 0.028 & -0.008 & -0.248 & 0.805 \\
\hline Total & -0.038 & 0.032 & & -1.207 & 0.231 \\
\hline
\end{tabular}

As the economy and the rate of urbanization grew rapidly in Sorong, more and more rural labor surpluses left the countryside and flocked to big cities, and the floating population had skyrocketed. In recent years, family migration has become the primary mode of migration of the Sorong floating population, which means more and more parents are taking their children out of their permanent registered residences to new cities where they work and live. The number of teenagers in migrant families has increased dramatically over the past few years.

During this immigration process, children and adolescents in migrant families often have to face considerable pressure to adapt to life in the city, which causes various mental health problems. Evidence shows that the incidence rate of children's mental health problems in migrant families is higher than in nonmigrant families. (Xu et al., 2017) Parenting style is an essential factor in family education and is a relatively stable pattern of behavior and tendencies in raising and educating children through daily activities. The parenting style generally falls along a continuum between two weak and overly punitive anchors, with extremes in both directions defined as unfavorable. Positive parenting is a strategy that involves warmth, sensitivity, acceptance, and responsiveness to children (Kawabata et al., 2011). Previous studies have shown that parenting style and ideas are important influencing factors for children's psychological development and behavior. (Csomortáni, 2013)

Parenting style and ideas are important influencing factors for the psychological development and behavior of children. In studies of childcare styles in the families of shunt migrants and eastern Indonesia, parents tend to usually adopt some negative parenting styles (for example, punishment and authoritarianism) and rarely adopt positive parenting styles (for example, emotional warmth and understanding). According to (Llorca et al., 2017; Verhoeven et al., 2012) reported that poor parenting style would increase the incidence rate of children's psychological problems, and negative parenting styles, such as excessive protection and excessive interference, were more likely to increase a child's social anxiety. A parenting style that is refusing, overprotective, and anxious is related to increasing children's anxiety. A study from China also found that parental orders and reprimands negatively correlated with adolescent selfesteem and emotional balance and positively related to social anxiety and behavior problems. (Liu et al., 2019) Besides, mothers of daughters with high social anxiety tend to control and assist their daughters in their daily lives and learning.

Furthermore, fathers of children with high anxiety show more controlling behavior (Greco \& Morris, 2002). Most of this research, however, mainly focus on childcare style and social anxiety in non-migrant families. At the same time, several studies examine the relationship between parenting style and the social anxiety of adolescents in migrant families.

Parental warmth and effective parenting behaviors (such as the use of appropriate boundaries and disciplines) distinguish tough children from those who have more social and emotional problems among school-age children who are exposed to physical violence and the threat of violence against their mother. Besides, the lack of warmth and support that characterizes authoritarian parenting styles undermines parent-child relationships. It causes children to rebel against their parents' demands, potentially in the form of externalizing problems, or to display overly submissive behavior, which can manifest themselves in the internalizing problem. Indeed, empirical studies have shown that authoritarian parenting is associated with externalization as well as internalization problems in children, concerning permissive styles, research has shown that permissive mothering significantly predicts the development of externalizing behavior in toddlers. (Rinaldi \& Howe, 2012) Furthermore, parental refusal to teach children that positive outcomes (eg, warmth and parental consent) are rare and do not depend on one's actions and this uncertainty can prevent attempts at children's independence. (Varela et al., 2013).

In this study, we found that respecting and respecting and increasing motivation. The perspective of adolescents would be very suitable for use during transitions such as youth and young adults, where autonomy is an important developmental task. In a long-term view, stabilizing mental conditions in adolescents can lead to better control of chronic conditions and the prevention of life-long mental health consequences. 


\section{SOCIAL SCIENCE}

\section{International Journal of Environmental, Sustainability, and Social Sciences ISSN 2720-9644 (print); ISSN 2721-0871 (online) \\ https://journalkeberlanjutan.com/index.php/IJESSS}

Acording to (Reinauer et al., 2018) found that motivation can reduce comorbidity, increase long-term adherence to therapy, and can change maladaptive health dysfunctional behavior, which can become chronic in adolescence and early adulthood. Methods for overcoming individual and structural barriers to the use of mental health services, which must be identified and reduced in the long-run. Our results are consistent with previous studies, which also confirm that there is a significant relationship between achievement motivation and psychological well-being (Nisa \& Qasim, n.d.; Nwankwo et al., 2018; Li et al., 2015). Achievement motivation can be considered as the main introduction to success in adolescents in the future. In general, those who are motivated to be successful are more interested in moving towards the future and pay attention to innovation activities from an early age.

Teenagers in Indonesia generally spend more than 6 hours a day and an average of nearly 1,200 hours each year in school. Therefore, it is not surprising that schools have a considerable influence on adolescent mental health and may even be more influential than the home environment. Therefore, school policies can be encouraged to improve the mental health of adolescents.

In overcoming this need, (Lau et al., 2018) promoting student style of students to identify aspects of school discipline that might be able to estimate the mental health risks of adolescents. The four sections that are the focus of research are drug use, violent aggression, intimidation involvement, and depressive symptoms. The result found is that the style of educating teenagers in authoritative schools has the lowest risk, while adolescents in schools that are too loose have the highest risk.

The results of this study are in line with the results of this study, which found that the majority of respondents experienced negative parenting that is authoritarian from their parents but did not have a linear relationship with their mental health. This means that authoritarian parenting that is the culture of eastern societies in Indonesia, has a positive impact because it does not reduce the motivation and discipline of adolescents. Most important is mental health is a significant impact on adolescent development because it can affect their discipline and motivation even if the teenager must be educated in an authoritarian way or not.

The era of technology supports teenagers to create their world and environment because they can access the best information, including parenting. Besides, the era of technology can open up parents' insight to educate children, and children can freely invite parents to discuss.

The results of this study require further study considering the place of this research was conducted in eastern Indonesian people who have harsh behavior, and the distribution of education and technology is less evenly distributed compared to central and western Indonesia. Besides, research with a larger sample is needed to understand the appropriateness of school discipline styles with parental discipline styles. Similar findings for school discipline styles have implications for how school professionals conceptualize their role in facilitating a warm and structured environment.

The current study raises new questions about how to produce broad policy changes that are in line with the conceptualization of the principles of discipline, parenting parents, and the promotion of effective motivation specifically for adolescents. Moreover, how to facilitate the implementation of school discipline policies and authoritative parenting parents.

\section{CONCLUSION}

The results of this study found that simultaneously, parenting, discipline, and motivation have a linear relationship with adolescent mental health. However, separately, only discipline and motivation have a close relationship with health. Parenting patterns do not have a linear relationship with adolescent mental health.

\section{REFERENCE}

Atkins, M. S., Shernoff, E. S., Frazier, S. L., Schoenwald, S. K., Cappella, E., Marinez-Lora, A., Mehta, T. G., Lakind, D., Cua, G., Bhaumik, R., \& Bhaumik, D. (2015). Redesigning community mental health services for urban children: Supporting schooling to promote mental health. Journal of Consulting and Clinical Psychology, 83(5), 839-852. https://doi.org/10.1037/a0039661

Bloemraad, I., \& Terriquez, V. (2016). Cultures of engagement: The organizational foundations of advancing health in immigrant and low-income communities of color. Social Science \& Medicine (1982), 165, 214222. https://doi.org/10.1016/j.socscimed.2016.02.003

Csomortáni, D. Z. (2013). [Prospective study of children's perceptions of parental behavior: Psychometric properties of the Hungarian version of the EMBU-C questionnaire]. Psychiatria Hungarica: A Magyar Pszichiatriai Tarsasag Tudomanyos Folyoirata, 28(4), 399-413.

Dwairy, M., \& Menshar, K. E. (2006). Parenting style, individuation, and mental health of Egyptian adolescents. Journal of Adolescence, 29(1), 103-117. https://doi.org/10.1016/j.adolescence.2005.03.002

Greco, L. A., \& Morris, T. L. (2002). Paternal Child-Rearing Style and Child Social Anxiety: Investigation of Child Perceptions and Actual Father Behavior. Journal of Psychopathology and Behavioral Assessment, 24(4), 259-267. https://doi.org/10.1023/A:1020779000183

Hetrick, S. E., Cox, G. R., Witt, K. G., Bir, J. J., \& Merry, S. N. (2016). Cognitive-behavioral therapy (CBT), third-wave CBT, and interpersonal therapy (IPT) based interventions for preventing depression in children 


\section{SOCIAL SCIENCE}

\section{International Journal of Environmental, Sustainability, and Social Sciences ISSN 2720-9644 (print); ISSN 2721-0871 (online) \\ https://journalkeberlanjutan.com/index.php/IJESSS}

and adolescents. Cochrane Database of Systematic Reviews, 8. https://doi.org/10.1002/14651858.CD003380.pub4

Kawabata, Y., A link, L. R. A., Tseng, W.-L., van IJzendoorn, M. H., \& Crick, N. R. (2011). Maternal and paternal parenting styles associated with relational aggression in children and adolescents: A conceptual analysis and meta-analytic review. Developmental Review, 31(4), $240-278$. https://doi.org/10.1016/j.dr.2011.08.001

Kia-Keating, M., Santacrose, D. E., Liu, S. R., \& Adams, J. (2017). Using Community-Based Participatory Research and Human-Centered Design to Address Violence-Related Health Disparities Among Latino/a Youth. Family \& Community Health, 40(2), 160-169. https://doi.org/10.1097/FCH.0000000000000145

Lau, C., Wong, M., \& Dudovitz, R. (2018). School Disciplinary Style and Adolescent Health. Journal of Adolescent Health, 62(2), 136-142. https://doi.org/10.1016/j.jadohealth.2017.08.011

Li, Y., Lan, J., \& Ju, C. (2015). Self-esteem, gender, and the relationship between extraversion and subjective well-being. Social Behavior and Personality, 43(8), https://doi.org/10.2224/sbp.2015.43.8.1243-1254

Liu, L., Wang, N., \& Tian, L. (2019). The Parent-Adolescent Relationship and Risk-Taking Behaviors Among Chinese Adolescents: The Moderating Role of Self-Control. Frontiers in Psychology, 10. https://doi.org/ 10.3389/fpsyg.2019.00542

Llorca, A., Cristina Richaud, M., \& Malonda, E. (2017). Parenting, Peer Relationships, Academic Self-efficacy, and Academic Achievement: Direct and Mediating Effects. Frontiers in Psychology, 8. https://doi.org/10.3389/fpsyg.2017.02120

Nisa, S. U., \& Qasim, N. (n.d.). Relationship of achievement motivation and psychological well-being in adolescents. 3.

Nwankwo, C., Okeke, C. P., \& Okeke, O. J. (2018). Impact of Motivation on the Psychological Wellbeing of Nurses in Enugu Metropolis. International Journal of Academic Research in PSYCHOLOGY, 5(1), 14.

Puffer, E. S., Green, E. P., Sikkema, K. J., Broverman, S. A., Ogwang-Odhiambo, R. A., \& Pian, J. (2016). A church-based intervention for families to promote mental health and prevent HIV among adolescents in rural Kenya: Results of a randomized trial. Journal of Consulting and Clinical Psychology, 84(6), 511-525. https://doi.org/10.1037/ccp0000076

Reinauer, C., Biermann, R., Förtsch, K., Linderskamp, H., Warschburger, P., Holl, R. W., Staab, D., Minden, K., Muche, R., Leonhardt, M., Baumeister, H., Meissner, T., \& COACH consortium. (2018). Motivational Interviewing as a tool to enhance access to mental health treatment in adolescents with chronic medical conditions and need for psychological support (COACH-MI): Study protocol for a cluster-randomized controlled trial. Trials, 19(1), 629. https://doi.org/10.1186/s13063-018-2997-5

Reitman, D., Rhode, P. C., Hupp, S. D. A., \& Altobello, C. (2002). Development and Validation of the Parental Authority Questionnaire-Revised. Journal of Psychopathology and Behavioral Assessment, 24(2), $119-127$. https://doi.org/10.1023/A:1015344909518

Rinaldi, C. M., \& Howe, N. (2012). Mothers' and fathers' parenting styles and associations with toddlers' externalizing, internalizing, and adaptive behaviors. Early Childhood Research Quarterly, 27(2), $266-273$. https://doi.org/10.1016/j.ecresq.2011.08.001

Suranto. (2009). Hubungan Antara kesehatan mental dan motivasi belajar Dengan kedisiplinan siswa kelas xi SMA Negeri di Kecamatan purbalingga Kabupaten purbalingga Tahun pelajaran 2008/2009 [Ph.D., Universitas Sebelas Maret]. https://eprints.uns.ac.id/8173/

Varela, R. E., Niditch, L. A., Hensley-Maloney, L., Moore, K. W., \& Creveling, C. C. (2013). Parenting practices, interpretive biases, and anxiety in Latino children. Journal of Anxiety Disorders, 27(2), 171177. https://doi.org/10.1016/j.janxdis.2012.12.004

Vereinte Nationen, \& Büro für Drogenkontrolle und Verbrechensbekämpfung. (2019). World drug report, 2019.

Verhoeven, M., Bögels, S. M., \& van der Bruggen, C. C. (2012). Unique Roles of Mothering and Fathering in Child Anxiety; Moderation by Child's Age and Gender. Journal of Child and Family Studies, 21(2), 331343. https://doi.org/10.1007/s10826-011-9483-y

WHO. (2019). Adolescent mental health. https://www.who.int/news-room/fact-sheets/detail/adolescentmental-health

Xu, F., Xing, H., Yu, W., Chen, S., \& Li, H. (2017). Health-related quality of life and influencing factors among migrant children in Shaoxing, China. Health and Quality of Life Outcomes, 15(1), 100. https://doi.org/10.1186/s12955-017-0679-8 